Journal of Pharmaceutical Science and Medical Research

Vol. 4, No.1, Februari 2021, hal $25-31$

ISSN (print): 2614-4840 ISSN (online): 2614-6118

Avaliable online at: http://e-journal.unipma.ac.id/index.php/pharmed

\title{
HUBUNGAN DAMPAK PERCERAIAN ORANG TUA TERHADAP KESEHATAN MENTAL ANAK USIA SEKOLAH TAHUN DI KOTA KOTAMOBAGU
}

\author{
Henny Kaseger \\ Prodi S1 Keperawatan Institut Kesehatan dan Teknologi Graha Medika \\ JI. Raya AKD RSI Moonow Lantai II, Mongkonai Barat, Kotamobagu \\ e-mail: hennykaseger01@gmail.com
}

\begin{abstract}
Abstrak
Setiap terjadinya perceraian orang tua sudah barang tentu berdampak negatif terhadap proses pendikan dan perkembangan jiwa anak, di karenakan anak usia sekolah dasar pada umumnya masih membutuhkan kasih sayang dan perhatian penuh dari kedua orang tua. Perceraian orang tua merupakan problema yang cukup besar bagi anak- anaknya terutama bagi anak-anak yang masih sekolah dasar, sebab anak-anak pada usia ini masih sangat membutuhkan kasih sayang kedua orang tuanya. Pengalaman yang diperoleh anak di waktu kecil baik pengalaman pahit maupun menyenangkan semuanya memberi pengaruh dalam kehidupan anak nantinya. Tujuan Penelitian: Penelitian ini untuk mengetahui hubungan dampak perceraian orang tua terhadap kesehatan mental anak usia sekolah $3-12$ tahun di kotamobagu. Metode Penelitian: menggunakan metode deskriptif analitik dengan pendekatan crossectional study. Penelitian ini menggunakan instrumen kuesioner dan analisa data menggunakan uji chi-square. Hasil penelitian: berdasarkan uji chi-square menunjukan adanya hubungan antara ke dua variabel didapat $p$ value $=0,046$ sehingga dapat disimpulkan bahwa terdapat hubungan dampak perceraian orang tua terhadap kesehatan mental anak usia sekolah di Kotamobagu. Saran: Penelitian ini diharapkan sebagai sarana pemberian edukasi yang dapat membuat responden lebih mengetahui dampak perceraian orang tua terhadap kesehatan mental pada anak usia sekolah.
\end{abstract}

Kata kunci: Dampak perceraian, kesehatan mental, anak usia sekolah

\section{THE RELATIONSHIP THE IMPACT OF PARENTAL DIVORCE AND THE MENTAL WELL-BEING OF SCHOOL-AGED CHILDREN IN THE CITY OF KOTAMOBAGU CITY}

\begin{abstract}
Every occurrence of parental divorce, of course, has a negative impact on the educational process and mental development of children, because elementary school-age children generally still need full love and attention from both parents. Parental divorce is a big problem for their children, especially for children who are still in elementary school, because children at this age still really need the love of their parents. The experiences that children get in their childhood, both bitter and pleasant experiences, all have an impact on the child's life later. Research Objectives: This study was to determine the relationship between the impact of parental divorce on the mental health of school age children 3-12 years in Kotamobagu. Methods: using a descriptive analytic method with a cross-sectional study approach. This study used a questionnaire instrument and data analysis using the chi-square test. The results: based on the chi-square test showed a relationship between the two variables obtained $p$ value $=0.046$ so it can be concluded that there is a relationship between the impact of parental divorce on the mental health of school-age children in Kotamobagu. Suggestion: This research is expected as a means of providing education that can make respondents more aware of the impact of parental divorce on mental health in school-age children.
\end{abstract}

Keywords: Impact of divorce, mental health, school age children 


\section{Pendahuluan}

Setiap terjadinya perceraian orang tua sudah barang tentu berdampak negatif terhadap proses pendikan dan perkembangan jiwa anak, di karenakan anak usia sekolah dasar pada umumnya masih membutuhkan kasih sayang dan perhatian penuh dari kedua orang tua. Hal ini akan dibuktikan nantinya dalam pembahasan berkutnya, hal-hal yang berkaitan dengan dampak yang dirasakan anak akibat terjadinya perceraian kedua orang tuanya. Perceraian orang tua merupakan problema yang cukup besar bagi anak- anaknya terutama bagi anak-anak yang masih sekolah dasar, sebab anak-anak pada usia ini masih sangat membutuhkan kasih sayang kedua orang tuanya. Suasana rumah tangga memberi pengaruh terhadap perkembangan dan pendidikan anak usia Sekolah Dasar. Suasana keluarga yang berantakan dapat menyebabkan anak tidak dapat belajar dengan baik bahkan membawa pengaruh yang negatif terhadap perkembangan jiwa anak dalam masa pertumbuhannya, karena pribadi si anak umumnya terjadi melalui pengalaman yang didapat diwaktu kecil. Pengalaman yang diperoleh anak di waktu kecil baik pengalaman pahit maupun menyenangkan semuanya memberi pengaruh dalam kehidupan anak nantinya.(MY Yusuf, 2014)

Perkara perceraian di Sulawesi Utara di akhir tahun 2018 mengalami peningkatan mencapai 1.706 perkara yang diputuskan dari 1.752 perkara yang diterima. Wakil Ketua Pengadilan Tinggi Agama Manado, Drs. H. Izzuddin, HM, SH, $\mathrm{MH}$ mengatakan, angka perceraian di sulawesi utara meningkat didominasi oleh cerai gugat yang di ajukan istri dan perkara cerai talak yang di ajukan suami. Data tersebut diambil dari semua Pengadilan Agama di Provinsi Sulawesi Utara. Untuk perkara banding yang di ajukan ke Pengadilan Tinggi Agama Manado meningkat, oleh karena tahun sebelumnya hanya 4 perkara banding yang diputuskan, tahun ini sampai dibulan Oktober 2018 ada 13 perkara, 12 perkara sudah di putuskan, 1 masih dalam proses. Diakui, dari perkara cerai yang meningkat ini diambil positifnya, jumlah perkara cerai ini bisa mencapai hampir 2.000 perkara, hal tersebut menunjukkan masyarakat sadar hukum, oleh karena tidak bertindak sendiri untuk perkara hukum, karena lebih mempercayakan pengadilan untuk proses hukum. Dilihat dari data yang di keluarkan pengadilan Tinggi Agama Manado, daerah Kota Kotamobagu perkara perceraian dengan angka tertinggi di Sulawesi Utara yang kemudian di ikuti Kota Manado. (RRI, 2019).

Berdasarkan data yang di himpun petugas Panitera PA Kotamobagu, tercatat perkara yang sudah putus cerai baik cerai talak dan cerai gugat sejak Januari-Juli 2020 sebanyak 216, dibanding periode yang sama di tahun 2019 ada 202 perkara putus cerai. Berdasarkan data perceraian yang ditangani PA Kotamobagu pada tahun 2019 lalu, untuk periode Januari hingga Desember, dari permohonan sebanyak 1.039, Pengadilan telah memutuskan 358 perkara, khusus cerai talak sebanyak 73 perkara dan cerai gugat mencapai 285 perkara.

Perceraian mempunyai pengaruh yang sangat besar terhadap perkembangan jiwa dan pendidikan anak, terutama anak usia sekolah dasar. Diantaranya dapat menyebabkan anak bersikap pendiam dan rendah diri, nakal yang berlebihan, prestasi belajar rendah dan merasa kehilangan. Walaupun tidak pada semua kasus sama, tapi sebagian besar menimbulkan dampak negatif terhadap perkembangan jiwa anak dan juga berpengaruh terhadap proses pendidikan anak itu sendiri. Pada umumnya anakanak yang keluarganya bercerai ikut bersama ibunya, dan semua biaya hidupnya yang seharusnya menjadi tanggung jawab bapak tetapi menjadi tanggung jawab si ibu. Anak-anak dari keluarga sempuma memiliki prestasi lebih baik dibandingkan dengan anak-anak dari keluarga tidak sempuma yang orang tua nya bercerai. Dampak perceraian orang tua juga terlihat secara nyata bagi anak-anak usia sekolah dasar seperti pendiam, pemalu, tidak lagi ceria dan prestasi belajarnya menurun serta berdampak pada kesehatan mental. (Mahabati, 2016). 


\section{Metode Penelitian}

Penelitian ini merupakan jenis penelitian kuantitatif yang menggunakan metode deskriptif analitik dengan pendekatan crossectional study, dimana peneliti akan memfokuskan penelitian pada hubungan variabel independen dan variabel dependen. Desain penelitian ini menggunakan penelitian deskriptif analitik dan menggunakan pendekatan cross sectional yaitu pengumpulan data dua variabel dilakukan dalam satu waktu (Donsu, 2017). Penelitian ini telah dilaksanakan di Tk Aisyiyah Bustanul Athfal (ABA) II Al - Huda Gogagoman, SDN 1 Poyowa Kecil dan di SDN 3 Kotamobagu. Penelitian ini telah dilaksanakan pada bulan Mei s/d Juni 2019. Populasi adalah seluruh objek penelitian. Pada penelitian ini populasinya adalah semua anak sekolah di Tk Aisyiyah Bustanul Athfal (ABA) II Al - Huda Gogagoman, di SDN 1 Poyowa Kecil, dan di SDN 3 Gogaoman berjumlah 33 anak.

Jumalah Populasi sudah diketahui jumlahnya maka pengambilan jumlah sampel penelitian ini menggunakan pengambilan sampel adalah teknik total sampling yaitu mengambil sampel dari seluruh populasi, Jadi jumlah sampel adalah 33 anak. Analisis data dilakukan dalam bentuk univariat dan bivariat.

Analisa univariat untuk mendapatkan gambaran distribusi frekuensi dari variabel-variabel penelitian yaitu peran keluarga dan dampak negatif penggunaan gadget pada anak. Analisis dilakukan dengan statistik deskriptif berupa distribusi frekuensi. Analisa bivariat bertujuan untuk mengetahui ada tidaknya hubungan yang bermakna antara variabel bebas peran keluarga dan dampak negatif penggunaan gadget pada anak. Analisis dilakukan dengan uji Chi-Square pada analisis ini dilakukan pengujian risk estimate agar didapatkan OR (odds ratio). OR diperlukan untuk menilai peluang dari variabel bebas terhadap variabel terikat.

\section{Hasil Penelitian}

\section{Karakteristik Responden.}

\section{a. Analisis Univariat}

Tabel 1. Distribusi Responden Berdasarkan Umur

\begin{tabular}{ccc}
\hline Usia Responden & $\mathbf{n}$ & $\%$ \\
\hline$<9$ tahun & 12 & $36.4 \%$ \\
$\geq 9$ Tahun & 21 & $63.6 \%$ \\
\hline Total & 33 & $100.0 \%$ \\
\hline
\end{tabular}

Berdasarkan tabel 1 diatas dari 33 responden, sebanyak 21 responden (63.6\%) berusia di atas $\geq 9$ tahun dan 12 responden (36.4\%) berusia dibawah $<9$ tahun.

Tabel 2. Distribusi Berdasarkan Jenis Kelamin

\begin{tabular}{ccc}
\hline Jenis Kelamin & $\mathbf{n}$ & $\%$ \\
\hline Laki-Laki & 20 & $60.6 \%$ \\
Perempuan & 13 & $39.4 \%$ \\
\hline Total & $\mathbf{3 3}$ & $\mathbf{1 0 0 \%}$ \\
\hline
\end{tabular}

Distribusi responden diatas, dapat dijelaskan bahwa dari 33 responden, sebagian besar dengan jenis kelamin laki-laki (60.6\%) atau sebanyak 20 responden dan 20 responden (39.4\%) berjenis kelamin perempuan. 
Tabel 3. Distribusi Berdasarkan Kelas Responden

\begin{tabular}{|c|c|c|c|}
\hline No & Kelas & $\mathrm{n}$ & $\%$ \\
\hline 1 & TK & 8 & $24.2 \%$ \\
\hline 2 & SD & 25 & $75.8 \%$ \\
\hline \multicolumn{2}{|c|}{ Total } & 33 & 100 \\
\hline
\end{tabular}

Distribusi responden berdasarkan Berdasarkan tabel 3 di atas dapat diketahui bahwa dari 33 responden dalam penelitian ini, sebagian responden sudah duduk di bangku Sekolah Dasar yaitu sebanyak 25 responden $(75.8 \%)$, dan yang memiliki masih berada di taman kanak-kanan sebanyak 8 responden $(24.2 \%)$.

Tabel 4. Distribusi Berdasarkan Dampak Perceraian Orang Tua

\begin{tabular}{|c|c|c|c|}
\hline No & $\begin{array}{c}\text { Dampak } \\
\text { Perceraian }\end{array}$ & $\mathbf{n}$ & $\%$ \\
\hline 1 & Negativ & 16 & $48.5 \%$ \\
\hline 1 & Positiv & 17 & $51.5 \%$ \\
\hline \multicolumn{2}{|c|}{ Total } & 33 & $100 \%$ \\
\hline
\end{tabular}

Distribusi responden diatas, dapat dijelaskan bahwa dari dari 33 responden dalam penelitian ini, dampak negatif akibat perceraian sebanyak 16 Responden (48,5\%), dan yang berdampak positif sebanyak 17 responden (51,5\%).

Tabel 5. Distribusi Berdasarkan Kesehatan Mental

\begin{tabular}{cccc}
\hline No & $\begin{array}{c}\text { Kesehatan } \\
\text { Mental }\end{array}$ & $\mathbf{n}$ & $\%$ \\
\hline 1 & Normal & 16 & $48.5 \%$ \\
2 & Ambang Batas & 11 & $33.3 \%$ \\
3 & Abnormal & 6 & $18.2 \%$ \\
\hline Total & & $\mathbf{3 3}$ & $\mathbf{1 0 0} \%$ \\
\hline
\end{tabular}

Distribusi responden diatas, dapat dijelaskan bahwa dari dari 33 responden dalam penelitian ini, responden yang memiliki perilaku normal sebanyak 16 responden (48.5\%), dan ambang batas sebanyak 11 responden (33.3\%) sedangkan yang abnormal sebanyak 6 responden (18.2\%).

\section{b. Analisis Univariat}

Hasil Tabulasi Hubungan Dampak Perceraian Orang Tua Terhadap Kesehatan Mental Anak Usia Sekolah di Kotamobagu

\begin{tabular}{|c|c|c|c|c|c|c|c|c|c|}
\hline \multirow{3}{*}{$\begin{array}{l}\text { Dampak } \\
\text { Perceraian } \\
\text { Orang Tua }\end{array}$} & \multicolumn{6}{|c|}{ Kesehatan Mental } & \multicolumn{2}{|c|}{ Total } & \multirow{3}{*}{$P$} \\
\hline & \multicolumn{2}{|c|}{ Normal } & \multicolumn{2}{|c|}{$\begin{array}{c}\text { Ambang } \\
\text { Batas }\end{array}$} & \multicolumn{2}{|c|}{ Abnormal } & \multirow{2}{*}{$\mathrm{n}$} & \multirow{2}{*}{$\%$} & \\
\hline & $\mathrm{n}$ & $\%$ & $\mathrm{n}$ & $\%$ & $\mathrm{n}$ & $\%$ & & & \\
\hline Negativ & 9 & $56.3 \%$ & 4 & $25.0 \%$ & 3 & $18.8 \%$ & 16 & $100.0 \%$ & \\
\hline Positiv & 7 & $41.2 \%$ & 7 & $41.2 \%$ & 3 & $17.6 \%$ & 17 & $100.0 \%$ & 0.046 \\
\hline Total & 16 & $48.5 \%$ & 11 & $33.3 \%$ & 6 & $18.2 \%$ & 33 & $100.0 \%$ & \\
\hline
\end{tabular}


Hasil uji korelasi dari variabel dampak perceraian orang tua dan kesehatan mental anak usia sekolah dengan menggunakan uji Chi Square terdapat hubungan dampak perceraian orang tua terhadap kesehatan mental anak usia sekolah di Kotamobagu. Hasil uji statistika didapat $p$ value $=0.046$.

\section{PEMBAHASAN}

\section{Dampak Perceraian}

Perceraian dapat diartikan sebagai berakhirnya hubungan suami istri karena ketidak cocokan antara keduanya dan diputuskan oleh hukum. Perceraian merupakan peralihan besar dalam penyesuaian dengan keadaan, anak akan mengalami reaksi emosi dan perilaku karena kehilangan salah satu orang tuanya. Anak akan membutuhkan dukungan, kepekaan dan kasih sayang yang lebih besar untuk membantu mengatasi kehilangan yang dialaminya selama masa sulit ini. Hubungan yang tidak rukun dengan orang tua akan lebih banyak menimbulkan kemarahan dan kecemburuan sehingga emosi ini akan cenderung menguasai kehidupan anak. (Rahmalia \& Sary, 2017)

Angka perceraian di Indonesia lima tahun terakhir terus meningkat, dari dua juta pasangan menikah, sebanyak 15 hingga 20\% bercerai. Sementara, jumlah kasus perceraian yang diputus Pengadilan Tinggi Agama seluruh Indonesia pada 2014 mencapai 382.231, naik sekitar 131.023 kasus dibanding tahun 2010 sebanyak 251.208 kasus. Sementara dalam persentase berdasarkan data Badan Peradilan Agama Mahkamah Agung, dalam lima tahun terakhir terjadi kasus Cerai Gugat mencapai $59 \%$ hingga $80 \%$. Penyebabnya sendiri ada beberapa faktor yang mempengaruhi, diantaranya masalah ekonomi, tidak ada tanggung jawab, kekerasan dalam rumah tangga, campur tangan orang tua, perpindahan agama, juga orang ketiga. Permasalahan mengenai perceraian diperkuat dengan data semakin banyaknya perceraian yang terjadi di Indonesia dari tahun ke tahun. (Baequni, 2016)

Berdasarkan tabel 4 di ketahui bahwa dari 33 responden dalam penelitian ini, dampak negatif akibat perceraian sebanyak 16 Responden (48,5\%), dan yang berdampak positif sebanyak 17 responden (51,5\%).

Berdasarkan penelitian yang dilakukan oleh (Amina et al., 2012) dampak psikologis terbagi menjadi dampak kognisi, dampak emosi dan dampak konasi/psikomotor yang kesemuanya mempengaruhi penyesuaian diri subjek yang berimbas pada dunia sosial. Hubungan yang baik dalam keluarga dapat memberikan rasa aman dan percaya diri pada anak sehingga anak dapat menjalankan tugas perkembangan masa pertumbuhannya dengan baik. Hubungan keluarga yang utuh diasumsikan dapat memberikan pengaruh yang besar terhadap kematangan emosi anak dalam menghadapi berbagai macam kesulitan dalam bergaul dengan orang lain di luar rumah. (Rahmalia \& Sary, 2017)

\section{Kesehatan Mental Anak}

Keluarga merupakan lingkungan sosial pertama bagi anak yang memberi dasar perilaku perkembangan sikap dan nilai kehidupan dari keluarga. Salah satunya adalah belajar menghormati orang yang lebih tua serta membantu menyelesaikan berbagai masalah yang timbul. Orangtua diharapkan dapat membantu anak dalam menyesuaikan diri dengan lingkungan untuk mengatasi masalah secara realistik dan simpati. Oleh karena itu, keluarga sebagai tempat untuk mengkondisikan pemberian nilai positif pada anak.(Nigrum, 2013)

Berdasarkan tabel 5 di atas dapat diketahui bahwa dari 33 responden dalam penelitian ini, responden yang memiliki perilaku normal sebanyak 16 responden $(48,5 \%)$, dan ambang batas sebanyak 11 responden $(33,3 \%)$ sedangkan yang abnormal sebanyak 6 responden (18,2\%). 
Banyak ilmuwan sosial menemukan masalah-masalah tingkah laku diantara anak-anak dari perkawinan-perkawinan yang bermasalah. Jika dikumpulkan bersama-sama penelitian ini membuktian bahwa perceraian dan konflik perkawinan dapat menempatkan anak pada suatu lintasan yang menjurus pada masalahmasalah berat yang akan dialaminya. Kesulitan dapat dimulai padaawal masa kanak-kanak dengan kesulitan bersosialisasi, yang menjurus pada penolakan oleh rekan sebaya, orang tua, karena terganggu oleh masalah-masalah mereka sendiri. Orang tua kurang mempunyai waktu dan perhatian kepada anak-anak sehingga anak menjadi kurang terkontrol dalam hal pendidikan, pergaulan. Pada awal masa remaja, banyak anak dari keluarga-keluarga yang retak telah tersandung ke dalam masalah kenakalan remaja, termasuk nilai-nilai yang merosot, tingkah laku seksual terlampau dini, penggunaan obat-obat terlarang dan tindakan kejahatan.

\section{Hubungan Dampak Perceraian Orang Tua Terhadap Kesehatan Mental Anak Usia} Sekolah.

Perceraian yang terjadi pada sepasang suami istri yang telah memiliki anak akan menimbulkan dampak pada kehidupan anak. Ikatan perkawinan yang telah terputus membuat peran ayah dan ibu tidak dapat berjalan sepenuhnya. Hal ini terjadi karena ayah dan ibu sudah tidak lagi tinggal di dalam satu rumah dengan anak-anak mereka. Perilaku yang ditunjukkan oleh anak di sini merupakan sebuah simbol sebagai dampak perceraian orang tuanya. Perilaku ini terjadi karena adanya pengetahuan anak mengenai perceraian kedua orang tuanya. Pengetahuan tersebut meliputi faktor perceraian, berapa lama perceraian tersebut terjadi hingga saat ini, dan lingkungan dimana anak tinggal. (Djamaludin Ancok et al., 2000)

Berdasarkan hasil tabulasi silang antara variabel bebas (Dampak Perceraian Orang tua) dengan variabel terikat (kesehatan mental anak usia sekolah) dengan menggunakan uji statistika Chi Square dari 33 responden, untuk kategori dampak perceraian orang tua yang berdampak negatif sebanyak 16 respoden di mana untuk kesehatan mental anak yang normal sebanyak 9 responden $(56,3 \%)$, perilaku perbatasan sebanyak 4 responden $(25,0 \%)$, dan untuk yang perilaku abnormal sebanyak 3 responden (18,8\%). Sedangkan untuk dampak positif sebanyak 17 responden dengan kategori perilaku normal sebanyak 7 responden $(41,2 \%)$, ambang batas sebanyak 7 responden $(41,2 \%)$ dan untuk perilaku abnormal sebanyak 6 responden $(18,2 \%)$. Hasil uji statistika didapat $p$ value $=0,046$, sehingga dapat disimpulkan bahwa terdapat Hubungan Dampak Perceraian Orang Tua Terhadap Kesehatan Mental Anak Usia Sekolah di kotamobagu.

Perceraian orang tua tidak hanya memberi dampak buruk bagi fisik anak, akan tetapi juga berdampak buruk bagi jiwa anak. Berbagai masalah tentang keluarga yang dapat berpengaruh pada kesehatan mental anak. Hal ini disebabkan karena orang tua yang mempertahankan egonya masing-masing sehingga mereka tidak mendapat jalan keluar dari masalah mereka dan para orang tua lebih memilih bercerai. (Djamaludin Ancok et al., 2000)

Keluarga yang tidak utuh disebabkan oleh perceraian orang tua yang memisahkan anak dari salah satu orang tuanya, sehingga anak tidak bisa mendapatkan kasih sayang dari kedua orang tuanya, perceraian membuat anak cenderung mendapat perlakuan yang tidak layak dari orang tua. Perceraian membuat anak kehilangan salah satu dari orang tuanya. Sehingga anak membutuhkan waktu yang lebih banyak lagi untuk dapat menyesuaikan diri dengan keadaan yang berbeda". Hal ini jelas dapat menghambat perkembangan kesehatan mental anak. (Musbikin, 2008) 


\section{Kesimpulan}

Berdasarkan hasil peneltitian di dapatkan sebagian besar perceraian berdampak positif sebanyak 17 responden (51,5\%). Berdasarkan hasil peneltitian sebagian besar responden memiliki kesehatan mental normal sebanyak 16 responden $(48,5 \%)$. Berdasarkan hasil uji statistika didapat $p$ value $=0,046$, sehingga dapat disimpulkan bahwa terdapat hubungan dampak perceraian orang tua terhadap kesehatan mental anak usia sekolah di kotamobagu.

\section{Saran}

1. Manfaat bagi tempat penelitian

Penelitian ini diharapkan sebagai sarana pemberian edukasi yang dapat membuat responden lebih mengetahui dampak perceraian orang tua terhadap kesehatan mental pada anak usia sekolah.

2. Manfaat bagi responden

Penelitian ini diharapkan sebagai sarana pemberian edukasi yang dapat membuat responden lebih mengetahui dampak perceraian orang tua terhadap kesehatan mental pada anak usia sekolah.

3. Manfaat bagi Institusi

Dapat digunakan sebagai data dasar dan referensi untuk penelitian selanjutnya dalam mengembangkan peneliti mengenai dampak perceraian orang tua terhadap kesehatan mental pada anak usia sekolah.

\section{Daftar Pustaka}

Amina, Andayani, T. R., \& Arif Karyanta, N. (2012). Proses Penerimaan Anak (Remaja Akhir) terhadap Perceraian Orangtua dan Konsekuensi Psikososial yang Menyertainya. Jurnal IImiah Psikologi Candrajiwa, 1(3), 57-68.

Baequni, A. (2016). Angka Perceraian di Indonesia Meningkat 80 Persen.

Djamaludin Ancok, Suroso, F. N., \& Ardan, M. S. (2000). Psikologi islami: Solusi islam atas problem-problem psikologi. In Pustaka Pelajar.

Mahabati, A. (2016). Identifikasi Anak dengan Gangguan Emosi dan Perilaku di Sekolah Dasar. Jurnal Pendidikan Khusus, 2(2).

Musbikin, I. (2008). Mengatasi Anak-anak Bermasalah.

MY Yusuf. (2014). Dampak Perceraian Orang Tua. Jurnal Al-Bayan, 20(1), 33-44.

Nigrum, P. R. (2013). Perceraian Orang Tua Dan Penyesuaian Diri Remaja. Jurnal IImiah Psikologi, 1(1), 39-44.

Rahmalia, D., \& Sary, N. (2017). Makna Pernikahan Pada Istri Yang Menggugat Cerai Suami. SEMNAS IIB DARMAJAYA, 83-100.

RRI, M. (2019). Sepanjang Tahun 2018, Disdukcapil Terbitkan 280 Akta Cerai. RRI.Co.Id. 